ISSN 0258-7122 (Print), 2408-8293 (Online)

Bangladesh J. Agril. Res. 42(3): 549-561, September 2017

\title{
ECONOMICS OF MAIZE GRAIN STORAGE AT HOUSEHOLD LEVEL IN CHUADANGA DISTRICT OF BANGLADESH
}

\author{
M. E. BAKSH ${ }^{1}$, F. ROSSI ${ }^{2}$, M. A. MOMIN ${ }^{3}$ \\ P. HAJONG ${ }^{4}$ AND T. P. TIWARI ${ }^{5}$
}

\begin{abstract}
There is a common perception among farmers and concerned professionals that maize grain cannot be stored like paddy or other cereals in conventional rural storage devices. As such, farmers generally sell their produce at harvest for any price offered to avoid quality deterioration and losing total return after harvest, which leads to lower profitability. To counter this situation, in the recent years, some progressive farmers at Chuadanga district (one of the concentrated maize growing area of Bangladesh) have been storing their maize grain within their household by using traditional bamboo granaries (Golas in the Bengali language) with the aim to capture higher future prices, while these Golas are traditionally used for storing paddy. Through the Cereal Systems Initiative for South Asia in Bangladesh (CSISA-BD) project, the International Maize and Wheat Improvement Center (CIMMYT) also helps further more to disseminate this technologies in the Chuadanga area. Given the uptake of this profitincreasing strategy by farmers, it is essential to document and evaluate the knowledge learned in order to inform scale-out efforts designed to reach farmers in other areas. A survey was conducted to assess maize grain storage systems in use at the household level in Chuadanga District farmers, and to estimate the overall profitability of storing maize grain. The survey results showed that approximately $80 \%$ of the total maize grain produced in 2014 (5.93 t/ha, on average) by sampled farmers was stored; most households employed Gola $(62 \%)$ and/or jute sacks (55\%), among other options. Golas were their first preference, followed by storage systems that pair polythene bags with (respectively) jute sacks and plastic bags, and then several other options. On average, farmers stored their maize grain 25.6 weeks (2014), 21 weeks (2013), and 20.9 weeks (2012) while realizing a price benefit of BDT $2.16 / \mathrm{kg}$, BDT $4.72 / \mathrm{kg}$, and BDT $5.35 / \mathrm{kg}$ in the respective years. Despite the fact that average storage costs and average quantities stored both varied by less than $7 \%$ between 2012 and 2014, the profit per unit $(100 \mathrm{~kg})$ and profit per household was significantly less in 2014 (BDT 10,161) than in 2013(BDT 24,445) and 2012 (BDT 30,255), due to the much lower price differential obtained from maize grain storage in 2014. Examination of the total unit cost of storage reveals that the Golas were the most profitable storage system employed by the farmers and its profits helps farmers to improve their livelihood. Proper dissemination of
\end{abstract}

\footnotetext{
${ }^{1-3}$ Formerly with the International Maize and Wheat Improvement Center (CIMMYT), ${ }^{4}$ Scientific Officer (Ag. Economics), Bangladesh Agricultural Research Institute (BARI), Regional Agric. Research Station, Jessore, ${ }^{5}$ International Maize and Wheat Improvement Center (CIMMYT), Bangladesh.
} 
these practices (storing and Gola) could be helpful for the farmers at the intensive maize growing area. Limitation of drying space and higher labour cost were the two major problems faced by the farmers, introducing quick-drying devices (flatbed dryers) can solve both the problems. It can be established either by local service providers, or farmers organizing themselves for collective ownership of such equipment.

Keywords: Bangladesh, cost analysis, grain storage, Gola, granary, maize grain, profitability.

\section{Introduction}

Maize (Zea mays) is a cereal crop that can be grown in a fairly broad range of agro-climatic conditions. It is relatively a new crop within the rice-based cropping patterns of Bangladesh; until 2001-02, there were only trivial areas under cultivation at the national level (BBS, 2014). Due to high demand resulting largely from the poultry industry (Karim et al., 2010, Miah et al., 2014), which has burgeoned to meet the change in Bangladeshi diets towards greater protein content, maize is now an important cash crop for the farmers who grow it. During 2013-14, area under maize was 307287 hectares and production was 2.124 million mt (BBS, 2016), which was ranked third after rice and wheat in area and was second only to rice in terms of production. This cereal crop is a direct food substitute for both rice and wheat and, farm households is in Bangladesh begin to consume more of it, maize would benefit the undernourished and malnourished people of rural Bangladesh due to a higher nutritional content (Karim et al. $2010)^{\mathrm{a}}$. With a very high yield potential, maize must be considered an important crop for ensuring food security in a not-too-distant future that will hold 200+ million people.

Maize is acceptable to its growers mainly due to a lower cost of production and higher yields in comparison to that of rice (Rahman, 2011, Karim et al., 2010, Moniruzzaman et al., 2009, Uddin, 2008, Mohiuddin et al., 2007). Nevertheless, the challenge of increasing the rate of adoption and sustainability of maize depends on social acceptance and economic profitability (Miah et al., 2013). In addition, there is a common perception among farmers and concerned professionals that maize grain cannot be stored like paddy or other cereals in conventional rural storage devices (maize grain has a large embryo and more fat content, inviting insects more quickly). Since maize is generally not consumed by Bangladeshi farmers', they never made any serious effort to store it. Thus, farmers generally sell their produce at harvest for any price offered to avoid quality deterioration and losing total return after harvest, which leads to lower

\footnotetext{
${ }^{\text {a }}$ Current human consumption of maize is very limited outside of the Chittagong Hill Tracts area, but there are places where maize is consumed in the form of flour added to wheat flour, as popcorn (especially in Dhaka), as roasted kernels (sold as a crunchy snack by nut vendors), and boiled or roasted on the cob.
} 
profitability. In turn, they then lose out when the off-season price is much higher later in the year. To counter this situation, some progressive farmers have been storing their maize grain within their household by using traditional bamboo granaries (Golas in the Bengali language) with the aim to capture anticipated higher future prices (Momin et al., 2014).

Under the Cereal Systems Initiative for South Asia in Bangladesh (CSISA-BD) project, the International Maize and Wheat Improvement Center (CIMMYT), as part of its agricultural development interventions, conducted a maize storage trial in Chuadanga District during the period July-October 2012. The objective was to compare three maize grain storing systems against locally-made bamboo granaries in order to evaluate and select a suitable method of storing maize grain by Bangladeshi farmers that could be promoted by the project. The Golas featured in the trial included project-promoted improvements in the form of tin sheet floors (and other upgrades) in order to deter rodents.
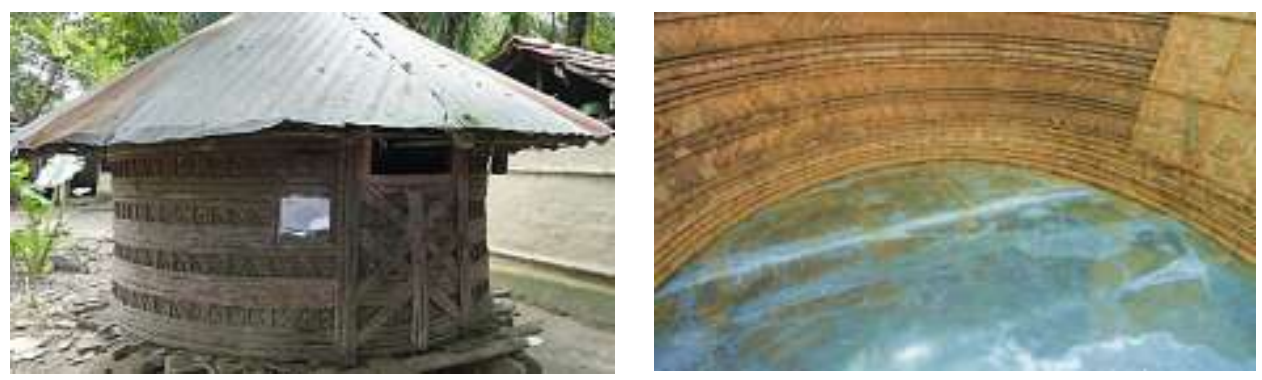

Figure 1. Locally-made bamboo Gola (left); inside view of a Gola with a tin floor improvement (right).

Overall the Golas performed well in terms of grain quality, color, and rate of pest/disease infestation when compared to other devices like poly bags (Momin et al., 2014). Subsequently, the results were shared widely with all farmers/groups working with CSISA-CIMMYT in Jessore (especially Chuadanga district) during different project events such as trainings, farmers' field days, cross visits, etc. Given the uptake of this profit-increasing strategy by farmers in the Chuadanga area, it is essential to document and evaluate the knowledge learned in order to inform scale-out efforts designed to reach farmers in other areas. As such, this study has been taken with the following specific objectives.

a. to identify and catalog the common maize storage systems in use at the household level,

b. to performing a cost analysis and estimating the profitability of maize grain stored for each type of storage device and utilization of increased income from maize grain storage for house hold welfare,

c. to document the problems that farmers still encounter with respect to maize grain storage at the household level, and 
d. to suggest some recommendation to overcome the problems and scale out the locally made maize grain storage device for the welfare of maize growers in other maize growing areas.

\section{Materials and Method}

\section{Sampling procedure and sample size}

Table 1. Survey details by storage system

\begin{tabular}{l|c|c|c}
\hline \multicolumn{1}{c|}{ Storage system } & Targeted & Sampled & \% of targeted \\
\hline Gola (granary) & 88 & 63 & 72 \\
Storage in jute sacks & 51 & 36 & 71 \\
Storage in poly \& plastic bags & 6 & 4 & 67 \\
Storage in a pucca room & 8 & 6 & 75 \\
\hline \multicolumn{1}{c}{ Total } & $\mathbf{1 5 3}$ & $\mathbf{1 0 9}$ & $\mathbf{7 1}$ \\
\hline
\end{tabular}

Data for the present study were gathered from both primary and secondary sources. A sample frame was developed that consisted of 153 maize grain-storing households from 13 villages within 7 unions (a political administrative unit under upazila) under the Chuadaga Sadar and Alamdanga upazilas of Chuadanga District. Due to the limited numbers of farmers engaging in this activity, these villages were purposively selected considering the spatial concentration of households storing maize grain and/or their affiliation with project activities. As presented in Table 1, farmers were categorised into different groups by storage device; a total of 109 households were randomly selected from these groups. Focus Group Discussions (FGD) was also conducted to verify the collected quantitative data.

\section{Method of data collection and period of study}

Primary data were collected from selected households in Chuadanga District of western Bangladesh (approximately $160 \mathrm{~km}$ west of Dhaka) during September 2014; a revisit was done in January 2015 to collect missing data, especially price data from farmers that had not yet sold any grain. Data collection was conducted by the principal investigator (lead author) and a collaborator from the Bangladesh Agricultural Research Institute (BARI). The household-level survey was based on a 3-page questionnaire comprising 40 questions; each interview lasted an average of 70-80 minutes. Two FGDs were conducted using a list of 20 structured questions; on average, each FGD lasted approximately 90 minutes and included 8-9 participants. Secondary data were also collected from different published sources, such as the Bangladesh Bureau of Statistics (BBS), research reports, and project reports in order to compare against the primary data and to enable a more comprehensive understanding of the overall situation. 


\section{Analytical techniques}

The collected quantitative data were compiled; corrected, analyzed and descriptive statistical data are presented in tabular form and via graphs. A simple statistical regression model was also employed to analyse the data, as well. Finally, the cost analysis with regard to maize grain storage considering cost of the storage device, cost of grain drying and winnowing, the cost of pest protection measures used, etc. These costs were calculated for each individual household and then averaged on a categorical (device) basis. The returns from storing maize were calculated by considering the price benefit (differences in price between beginning time and grain sales time) and quantity stored. The profitability of maize grain storage was also estimated by calculating the gross margin (i.e. returns over variable costs).

\section{Results and Discussion}

\section{Storage Data and System Preferences}

The data on maize cultivation in 2013-14 by the sampled farmers (by farm size ${ }^{\mathrm{b}}$ ) were collected and presented in Table 2 . The mean cultivated area under maize was 0.958 hectare (ha) per household, with a mean yield of 10.1 tons per hectare ( $t /$ ha). This yield is considerably higher than the national average of $6.61 \mathrm{t} / \mathrm{ha}$ for 2012-13 (BBS, 2014), which is unsurprising because Chuadanga farmers consistently outperform the rest of the country in terms of maize yield. Across the farm size categories of the study, however, there is an overall difference of only slightly less than $1 \mathrm{t} / \mathrm{ha}$. Excluding the Large category, the difference narrows to only $0.18 \mathrm{t} / \mathrm{ha}$, suggesting that observed differences in production are mainly due to difference in area cultivated. Note that the area under maize cultivation is greater for Marginal \& Landless farmers ( $0.69 \mathrm{ha})$ as compared to Small farmers $(0.56 \mathrm{ha})$; this leads to a higher mean production for the Marginal $\&$ Landless farmers even though the Small farmers have a slightly higher mean yield. Overall mean production was 7.42 tons per household, which is heavily influenced by the Large farmers in terms of area cultivated and (to a lesser degree) higher yield.

Following the harvest for the 2013-14 growing season, on average $80 \%$ of the total maize grain produced was stored by the sampled farmers -this shows that these farmers are actively pursuing higher prices through storage. Interestingly, in terms of percentage stored, the Marginal \& Landless farmers stored the most grain (89\%), followed by the Large (87\%), and Medium farmers (80\%). On average, 5.9 tons per household (t/hh) were stored. As shown in Figure 2, the majority ( 85 households) stored between $2-8 \mathrm{t} / \mathrm{hh}$ of grain, with only 8 households storing less than 2 tons, and 4 households storing more than 16 tons.

\footnotetext{
${ }^{\mathrm{b}}$ Farm size is determined from farm holdings (i.e. total land owned + area leased/shared in - area leased/shared out to others). The categories specified (e.g. Small $=0.21-1.0$ ha) are based upon those used by the Bangladesh Bureau of Statistics (BBS, 2013).
} 
Table 2. Area, production, and storage statistics per household, by farm size category (2014)

\begin{tabular}{|c|c|c|c|c|c|}
\hline Particulars & $\begin{array}{l}\text { Marginal } \\
(<0.21 \mathrm{ha})\end{array}$ & $\begin{array}{l}\text { Small } \\
0.21-1.0 \text { ha) }\end{array}$ & $\begin{array}{l}\text { Medium } \\
1.01-3.0 \mathrm{ha})\end{array}$ & $\begin{array}{l}\text { Large } \\
>3.0 \mathrm{ha})\end{array}$ & Average \\
\hline $\begin{array}{l}\text { Respondent } \\
\text { (number) }\end{array}$ & 17 & 49 & 39 & 4 & -- \\
\hline Maize area cultivated (ha) & 0.686 & 0.556 & 0.920 & 1.255 & 0.958 \\
\hline Yield (t/ha) & 9.91 & 10.10 & 9.92 & 10.88 & 10.07 \\
\hline Production (t/hh) & 6.80 & 5.61 & 9.13 & 13.57 & 7.42 \\
\hline Storage (t/hh) & 6.06 & 4.23 & 7.27 & 11.82 & 5.93 \\
\hline $\begin{array}{l}\text { Stored }(\% \text { of tota } \\
\text { production })\end{array}$ & 89.2 & 75.3 & 79.6 & 86.5 & 80.0 \\
\hline
\end{tabular}

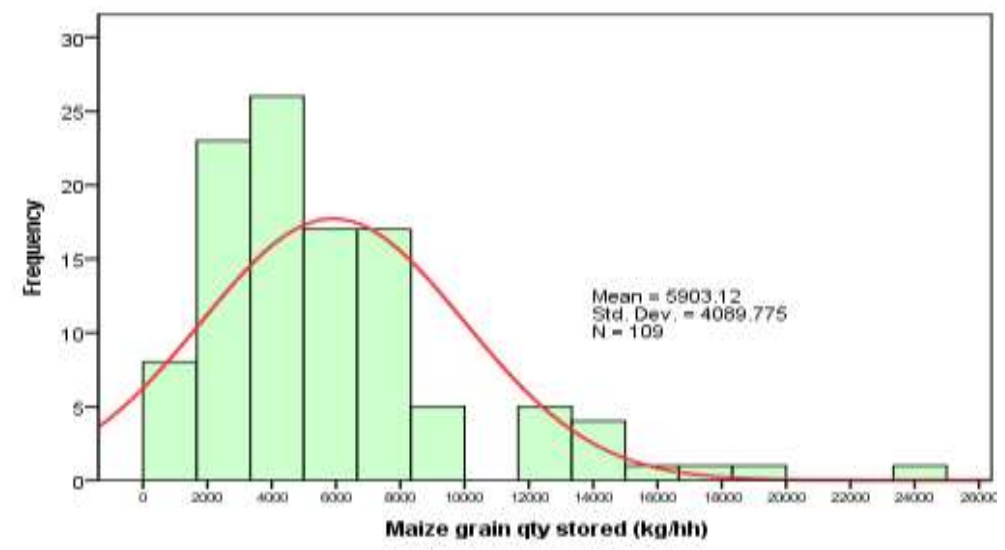

Fig. 2. Frequency distribution of maize grain quantity stored.

The study identified eight different systems used by sampled farmers to store maize grain..$^{\mathrm{c}}$ Table 3 displays the name of each storage system, as well as results of a simple preference ranking across the different options. The scale ranges from 1 to 7 ( $1=$ least preferred; $7=$ most preferred $)$; respondents were asked to take into consideration the availability, value, duration, cost, etc. of each system. On average, it was found that Golas were the most preferred storage option, followed by the poly bag/jute sack system, the poly bag/plastic bags system, and jute sacks. Although metal/plastic drums are air-tight and a very good option for storing grain, they were ranked last due to their high cost. Note that, while each of the surveyedfarmers usedat mosttwo devices at a time, they all stated that they had knowledge about each of the storage options under consideration.

${ }^{c}$ A storage system may include an individual device (e.g. a Gola) or a combination of devices (e.g. plastic bag inside a jute sack). 
Table 3. Average choice score and preference ranking of storage systems known/used

\begin{tabular}{l|c|c|c|c|c|c|c}
\hline & \multicolumn{7}{c}{ Storage system } \\
\cline { 2 - 8 } Ranking score & $\begin{array}{l}\text { Jute } \\
\text { sack }\end{array}$ & Plastic sack & $\begin{array}{c}\text { Poly bag } \\
\text { only }\end{array}$ & $\begin{array}{c}\text { Poly+ } \\
\text { Plastic } \\
\text { bag }\end{array}$ & $\begin{array}{c}\text { Poly+ } \\
\text { Jute sack }\end{array}$ & $\begin{array}{c}\text { Gola } \\
\text { (granary) }\end{array}$ & $\begin{array}{c}\text { Metal/ } \\
\text { Plastic } \\
\text { drum }\end{array}$ \\
\hline $\begin{array}{l}\text { Avg. choice } \\
\text { score }^{1}\end{array}$ & 4.01 & 2.58 & 3.10 & 4.62 & 4.86 & 6.68 & 2.12 \\
$\begin{array}{l}\text { Preference } \\
\text { ranking }\end{array}$ & 4 & 6 & 5 & 3 & 2 & 1 & 7 \\
\hline
\end{tabular}

${ }^{1}$ The preference score ranges from 1 (least preferred) to 7 (most preferred).

Table 4. Quantity stored, duration, and grain prices by principal storage systems utilized

\begin{tabular}{|c|c|c|c|c|c|c|c|c|}
\hline \multirow[b]{2}{*}{ Year } & \multirow[b]{2}{*}{ System } & \multirow{2}{*}{$\begin{array}{l}\mathrm{HHs} \\
(\%)\end{array}$} & \multicolumn{2}{|c|}{ Qty. stored } & \multirow{2}{*}{$\begin{array}{c}\text { Storage } \\
\text { duration } \\
\text { (weeks) }\end{array}$} & \multicolumn{3}{|c|}{ Maize grain price (BDT/100kg) } \\
\hline & & & $\mathrm{t} / \mathrm{hh}$ & $\%$ stored & & $\begin{array}{l}\text { At storage } \\
\text { time }\end{array}$ & $\begin{array}{l}\text { After } \\
\text { storage }\end{array}$ & Price diff. \\
\hline \multirow{5}{*}{2014} & Gola & 62 & 4.81 & 47 & 25.6 & 1,517 & 1,733 & 216.1 \\
\hline & Jute sack & 55 & 7.34 & 41 & 26.3 & 1,511 & 1,735 & 224.3 \\
\hline & $\begin{array}{l}\text { Plastic \& } \\
\text { poly bags }\end{array}$ & 7 & 6.07 & 4 & 25.5 & 1,500 & 1,694 & 193.8 \\
\hline & Pucca room & 6 & 9.10 & 8 & 22.3 & 1,513 & 1,688 & 175.0 \\
\hline & Average & & 5.93 & & 25.6 & 1,514 & 1,730 & 215.7 \\
\hline \multirow{5}{*}{2013} & Gola & 62 & 5.26 & 55 & 21.4 & 1,571 & 2,045 & 474.2 \\
\hline & Jute sack & 45 & 6.63 & 33 & 21.2 & 1,586 & 2,063 & 477.5 \\
\hline & $\begin{array}{l}\text { Plastic \& } \\
\text { poly bags }\end{array}$ & 9 & 5.75 & 5 & 19.2 & 1,575 & 2,030 & 455.0 \\
\hline & Pucca room & 6 & 6.83 & 7 & 19.2 & 1,585 & 2,013 & 427.1 \\
\hline & Average & & 5.77 & & 21.0 & 1,576 & 2,048 & 471.5 \\
\hline \multirow{5}{*}{2012} & Gola & 67 & 5.54 & 59 & 21.4 & 1,414 & 1,958 & 544.1 \\
\hline & Jute sack & 50 & 7.33 & 34 & 20.5 & 1,403 & 1,923 & 519.8 \\
\hline & $\begin{array}{l}\text { Plastic \& } \\
\text { poly bags }\end{array}$ & 6 & 7.07 & 4 & 20.0 & 1,400 & 1,917 & 516.7 \\
\hline & Pucca room & 2 & 9.20 & 4 & 16.0 & 1,400 & 1,913 & 512.5 \\
\hline & Average & & 6.19 & & 20.9 & 1,410 & 1,947 & 535.4 \\
\hline
\end{tabular}

As shown in Table 4, among the principal devices used by the sampled farmers to store their maize grain, $62 \%$ of farmers used a Gola to store $47 \%$ of the total stored grain in 2014. In 2013, Golas contained approximately 55\% of total stored grain, and $59 \%$ in 2012. Jute sacks were the second most popular device, used by $55 \%$ farmers in $2014,45 \%$ in 2013, and 50\% in 2012. 


\section{Price Differentials and Maize Storage Costs}

The duration of maize grain storage depends, in part, on price trends that vary from year to year. Table 4 shows that the holding period was greater in 2014 ( 25.6 weeks, ranging from 17 to 43 weeks) than in 2012 (20.9 weeks, ranging from 6 to 34 weeks). Nevertheless, the average storage price differentials (grain price at the time of storage less the sale price after storage) for each device were highest in 2012 and lowest in 2014. This indicates that year-to-year price variability-both at harvest time and subsequent sale prices - is more influential in determining the price spread than either the length of the storage period, or the type of storage device employed. For example, the length of storage time in 2014 was (on average) a month longer than in the two previous years, yet the average price differential was 54\% and 60\% less than in 2013 and 2012, respectively. Figure 3 also illustrates this with regressions contrasting 2014 with 2012. While the quadratic regression curve of 2014 data clearly shows that the positive rate of return of storage is increasing with time, the group of farmers who stored the longest (around 40 weeks) still received less of a spread than what the 2012 farmers obtained at 21 weeks.
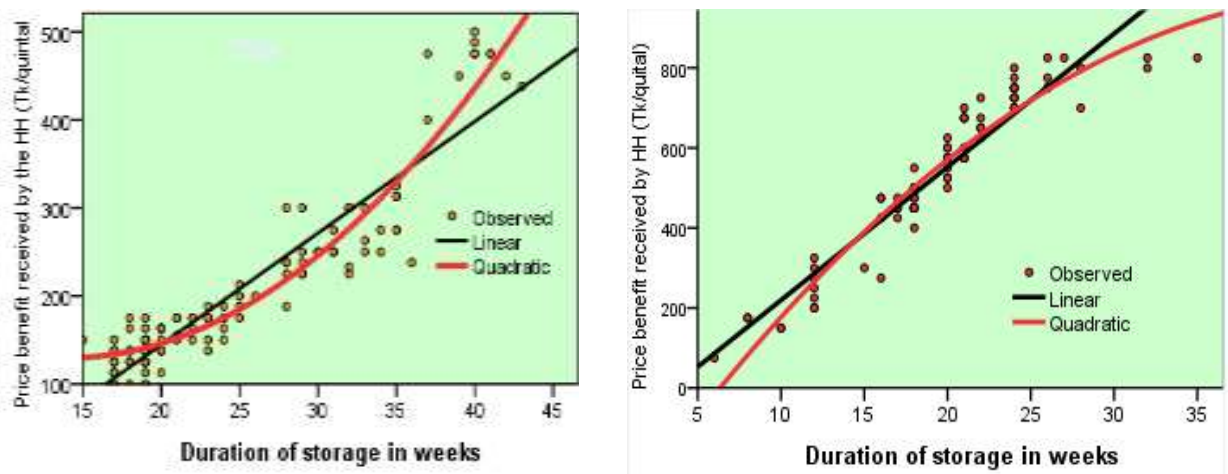

Figure 3. Regression of storage period against price benefit in 2014 (left) \& in 2012 (right).

The cost of the storage device was estimated considering the capacity of the container/device, unit price, longevity, cost of repairs, and the salvage value (if any). Note that only the rental cost of the room was considered for farmers storing maize in a pucca room. The average capacity was highest for pucca rooms (10.4 tons), followed by Golas (4.63 tons); the average device cost was greatest for jute sacks, at BDT 16.7 per $100 \mathrm{~kg}$, and least for Golas at BDT $12.9 / 100 \mathrm{~kg}$ (Table 5).

In addition to device cost, other costs involved with storage include the cost of drying and winnowing, the cost of pest protection, and grain loss costs. Before storing the grain, however, first it must be dried. Households reported a scarcity of open space where they can easily dry their maize grain. Maize grain was dried to approximately $12 \%$ moisture content after 3-4 days of exposure to sun on the 
roof of a building, on a pucca chatal/road, or on the ground either directly, or on top of a Trepal/cloth or a synthetic net. The majority of the farmers used the roof of their house $(35 \%)$ for maize grain drying, followed by a pucca road/chatal $(31 \%)$, and a Trepal/cloth (19\%) on the ground. Approximately $12 \%$ of farmers dried maize directly on the ground, while $3 \%$ used synthetic nets. Labour is the main component of the cost of drying and winnowing, most of which is shared by family members - especially women. Drying directly on the ground (BDT $29.38 / 100 \mathrm{~kg}$ ) and using a net (BDT $30.29 / 100 \mathrm{~kg}$ ) were the two most expensive options, because they required more time to dry the grain and therefore involved more labour, which ultimately increased the cost. The least expensive options were drying on the roof of a building (BDT $24.14 / 100 \mathrm{~kg}$ ), followed by drying on a pucca road/chatal (BDT 24.33/100kg).

Table 5. Component costs and other data used to estimate total unit cost of storage

\begin{tabular}{|c|c|c|c|c|c|c|}
\hline Storage system & $\begin{array}{l}\text { Capacity } \\
\text { (kg/unit) }\end{array}$ & $\begin{array}{c}\text { Unit } \\
\text { price of } \\
\text { device } \\
(\mathrm{BDT})\end{array}$ & $\begin{array}{c}\text { Device } \\
\text { longevity } \\
\text { (years) }\end{array}$ & $\begin{array}{c}\text { Repairing } \\
\text { cost, if any } \\
\text { (BDT/yr) }\end{array}$ & $\begin{array}{c}\text { Salvage } \\
\text { value } \\
\text { (BDT) }\end{array}$ & $\begin{array}{c}\text { Total unit } \\
\text { cost } \\
\text { (BDT/100 } \\
\mathrm{kg} \text { ) }\end{array}$ \\
\hline Gola & 4.629 & 10,587 & 76.1 & 429.4 & 1,051 & 12.93 \\
\hline Jute sack & 60 & 20.50 & 2.06 & 0 & 0 & 16.70 \\
\hline $\begin{array}{l}\text { Plastic \& poly } \\
\text { bags }\end{array}$ & 58 & 18.75 & 2.25 & 0 & 0 & 14.88 \\
\hline Pucca room & 10,400 & $\mathrm{n} / \mathrm{a}$ & $\mathrm{n} / \mathrm{a}$ & $1,267 *$ & $\mathrm{n} / \mathrm{a}$ & 13.68 \\
\hline
\end{tabular}

* The cost was for room rent

Table 6. Cost of storing maize grain at the household level (2014), in BDT / $100 \mathrm{~kg}$

\begin{tabular}{l|c|c|c|c|c}
\hline Storage system & Device cost & $\begin{array}{c}\text { Drying and } \\
\text { vinnowing cos }\end{array}$ & $\begin{array}{c}\text { Cost for } \\
\text { protection } \\
\text { measures }\end{array}$ & $\begin{array}{c}\text { Cost of } \\
\text { grain loss }\end{array}$ & $\begin{array}{c}\text { Total storage } \\
\text { cost of maize } \\
\text { grain }\end{array}$ \\
\hline Gola & 12.93 & 25.63 & 4.95 & 0 & 43.51 \\
Jute sack & 16.70 & 24.60 & 4.88 & 1.23 & 47.41 \\
$\begin{array}{l}\text { Plastic \& poly } \\
\text { bags }\end{array}$ & 14.88 & 25.00 & 4.33 & 0 & 44.21 \\
Pucca room & 13.68 & 26.79 & 3.13 & 0 & 43.60 \\
\hline \multicolumn{1}{c}{ Average } & $\mathbf{1 4 . 2 8}$ & $\mathbf{2 5 . 3 5}$ & $\mathbf{4 . 8 0}$ & $\mathbf{0 . 0 2}$ & $\mathbf{4 4 . 4 5}$ \\
\hline
\end{tabular}

Approximately $83 \%$ of the sampled farmers took preventative action against pests, of which $72 \%$ used Phostoxin (a fumigant that produces hydrogen phosphide gas), while 6\% sprayed an insecticide, and 5\% used both Phostoxine and an insecticide sprayed outside the granary and sacks (data not shown). Eighty-six percent of farmers using jute sacks applied one of the protection measures described above, followed by $83 \%$ of farmers using Golas, and $80 \%$ of 
farmers using plastic/poly bags. Farmers, those storing their maize in a pucca room, two-thirds of them took preventative action against pests. Across all protection methods, an average of BDT $4.80 / 100 \mathrm{~kg}$ was required for grain protection against pests. Overall, an extremely low amount of maize grain was damaged by insects/pests, affecting only the farmers using jute sacks or pucca rooms. In 2014, storage losses were only $0.10 \%$, which is equivalent to $5.9 \mathrm{~kg}$ per household. Storage losses were $0.48 \%$ in both 2013 and in 2012, which equals $27.7 \mathrm{~kg}$ and $29.7 \mathrm{~kg}$ grain lost per household, respectively. In monetary terms, grain losses per household were BDT 90, BDT 439 and BDT 417 in 2014, 2013 and 2012, respectively. Table 6 summarizes the various costs involved in storing maize grain during 2014 for each storage device. The jute sack system was the costliest (BDT 47.41/100 kg), while Golas (BDT 43.51/100 kg) were the most economical system, although storage in a pucca room was nearly identical in cost (BDT 43.60/100 kg).

\section{Profitability of Maize Storage}

The amount of profit earned through is presented in Table 7 for each system. Profits were estimated by deducting the total costs of storage from the price differential obtained (from Table 4) through household storage. The average profit obtained, across all storage types, was BDT 171.3/100 kg. The jute sack system was the most profitable system, and was 35\% higher than the pucca room system (the least profitable). Storage in Golas ranked second in terms of profitability, only slightly behind ( $2 \%$ less) the jute sacks.

Table 7. Profit earned from storage of maize grain by system, in BDT/100 kg (2014)

\begin{tabular}{l|c|c|c}
\hline \multicolumn{1}{c|}{ Storage system } & Price benefit & $\begin{array}{c}\text { Total cost for storing } \\
\text { maize grain }\end{array}$ & Profit earned \\
\hline Gola & 216.1 & 43.51 & 172.6 \\
Jute sack & 224.3 & 47.41 & 176.9 \\
Plastic \& poly bags & 193.8 & 44.21 & 149.5 \\
Pucca room & 175.0 & 43.60 & 131.4 \\
\hline \multicolumn{1}{c}{ Average } & $\mathbf{2 1 5 . 7}$ & $\mathbf{4 4 . 4 5}$ & $\mathbf{1 7 1 . 3}$ \\
\hline
\end{tabular}

Table 8 shows the profit earned by household for each of the three years examined. The highest average profit per household was BDT 30,255 in 2012, followed by BDT 24,445 in 2013, and BDT 10,161 in 2014. As mentioned previously, year-to-year price fluctuations largely determine the magnitude of the price differential obtained from storage in any given year; as such, this will of course have the greatest influence on profitability. This is clearly illustrated in the table: average storage costs did not vary much by year (less than $7 \%$ between 2013 and 2014), nor did the average quantities stored at the household level (less than 7\% between 2012 and 2013), yet the profit per unit (100 kg) and profit per 
household is significantly less in 2014 than the two previous years because of the much lower price differential.

Table 8. Household-level profit earned from storing maize grain (2012-2014)

\begin{tabular}{ccccc|c|c}
\hline Storage year & $\begin{array}{c}\text { Price benefit } \\
(\mathrm{BDT} / 100 \mathrm{~kg})\end{array}$ & $\begin{array}{c}\text { Storage cost } \\
(\mathrm{BDT} / 100 \mathrm{~kg})\end{array}$ & $\begin{array}{c}\text { Storage profit } \\
(\mathrm{BDT} / 100 \mathrm{~kg})\end{array}$ & $\begin{array}{c}\text { Qty. stored } \\
(\mathrm{kg} / \mathrm{hh})\end{array}$ & $\begin{array}{c}\text { Net profit } \\
(\mathrm{BDT} / \mathrm{hh})\end{array}$ \\
\hline 2014 & 215.7 & $44.45^{*}$ & 171.3 & 5,933 & 10,161 \\
2013 & 471.5 & 47.69 & 423.8 & 5,768 & 24,445 \\
2012 & 535.4 & 46.95 & 488.5 & 6,194 & 30,255 \\
\hline
\end{tabular}

* Including storage losses.

Profits earned by storing maize grain were used to purchase/mortgage in additional land, invest in business and/or deposit savings for future needs purchased essential household needs such as food, clothes, health and educational costs, and it also enables the purchase of agricultural inputs and equipment, as well as items such as motorcycles, electronic equipment/appliances (e.g. radios, televisions, fans) etc. Clearly, profits from maize grain storage have improved the welfare of these farmers and their families.

\section{Constraints in storing maize grain}

Although the respondent farmers were very happy to generate income from storing maize grain, and they will continue this activity in the future, they still faced some problems - mainly in terms of space limitations for grain drying and winnowing. There is a scarcity of open space where they can easily conduct this work. Whereas larger farmers use the concrete roof of their house as a drying area, many farmers are constrained in terms of efficient drying because they do not have such type of house. Labour and time required for drying and winnowing was the second-most indicated problem with storage, followed by insect infestation, and then liquidity constraints. The latter problem manifests as an urgent need for cash at the time of harvest (or sometime thereafter) that precludes farmers from storing maize grain (or reduces the storage time). Finally, about $10 \%$ of the cost of storing maize grain is due to pest prevention measures, farmers reported insect infestation as the third ranked problem they faced.

\section{Conclusions and Recommendations}

a. Conclusions: Considering the total cost of storage, Golas are the most profitable storage system, followed closely by pucca rooms. Plastic/poly bags remain in the third-ranked position, although they are quite competitive with Golas and pucca rooms. The advantage of Golas resides in the fact that many farmers already own these traditional devices within which they store rice- thus it is simply a matter of awareness (perhaps a few small modifications, as well) that they can also be used to successfully stored maize. Storing maize grain in HH level shows very good income generating potentials; farmers can earn a good 
amount of profit without investing much capital. They felt wealthy with their income flow and improving their livelihood by using the profit.

The scarcity of open space for efficient drying of maize grain, more labour and time required for drying and winnowing were the main problems followed by insect infestation. Liquidity constraints were also problems to smaller farmers to continue storing longer period.

b. Recommendations: The systems of storing was found best in Gola coupled with its better return having no cost of plastic and poly-bags and being of very long life period. So, proper dissemination of these practices (storing and Gola) could be helpful for the farmers at the intensive maize growing area. An action plan to demonstrate and disseminate these low cost technologies by taking much motivational and orientation program is very essential; Government (through BARI, DAE) can take this responsibility by involving location specific NGOs also.

By introducing quick-drying devices can solve both two major problems of drying space and labour cost. Establishment of drying facilities (e.g. low-tech flatbed dryers, or perhaps more advanced and expensive blow dryers) can either by local service providers, or farmers organizing themselves for collective ownership of such equipment. Involvement of lower levels of financing (i.e. micro-credit with reasonable terms/conditions) will help farmers address the liquidity constraint they reported, which would allow them to store grain in pursuit of higher prices instead of forcing them to sell at the time of harvest (or sell early if they manage to store).

More research is required to define the specific insect-pest problems and the best alternatives for addressing them, while also taking into consideration the various chemicals used as treatment agents. Ideally, any such study examining storage pests and chemical responses would simultaneously examine the issue of aflatoxin, with respect to its prevalence in stored maize grain, as this poisonous mold is known to propagate in improperly stored staple commodities and has been detected at high levels in food items and poultry feed Bangladesh (Roy et al., 2013).

\section{References}

BBS. 2014. Statistical Pocketbook Bangladesh 2013. Bangladesh Bureau of Statistics (BBS), Statistics and Informatics Division, Ministry of Planning, Government of Bangladesh, Dhaka, April 2014.

BBS. 2016. Statistical Yearbook of Bangladesh - 2015, 32 nd Edition. Bangladesh Bureau of Statistics (BBS), Statistics Division, Ministry of Planning, Government of Bangladesh, Dhaka, May 2016.

Karim, M.R., Moniruzzaman, and Q.M Alam. 2010. "Economics of hybrid maize production in some selected areas of Bangladesh".Bangladesh J. Agril. Res. 35(1): 83-93. 
Momin, M.A. and R.A. Mondal. 2014. "Performance of Different Storage Methods on Quality and Market Price of Maize Grain.’Unpublished research report (draft), CSISA-CIMMYT, Jessore Hub.

Mohiuddin, M.,M.R. Karim, M.H. Rashid, and M.S. Huda. 2007. "Efficiency and sustainability of maize cultivation in an area of Bangladesh."Int. J. Sust. Crop Prod. 2(3): 44-52.

Miah, M.A.M.,T.M.B. Hossain, M.A. Matin, S. Hossain, Moniruzzaman, and R. Kumar. 2013. "Assessments of the maize situation, outlook and investment opportunities to ensure Food security in Bangladesh." Research report, Bangladesh Agricultural Research Institute (BARI), Gazipur, Bangladesh, and Indian Council of Agricultural Research (ICAR), Hyderabad, Andhra Pradesh, India.

Miah, M.A.M., T.M.B. Hossain, and R. Kumar. 2014. "Maize Production in Bangladesh: Way towards Self-sufficiency”. In: Prasanna, B.M., Vivek, B.S.,Sadananda, A.R., Jeffers, D., Zaidi, P.H., Boeber, C., Erenstein, O., Babu, R., Nair, S.K., Gerard, B., Jat, M.L., Palacios, N. and Pixley, K. (Eds.), Book of Extended Summaries, $12^{\text {th }}$ Asian Maize Conference and Expert Consultation on Maize for Food, Feed, Nutrition and Environmental Security. Bangkok, Thailand, October 30 - November 1, 2014. CIMMYT, Mexico D.F. and APAARI, Bangkok, Pp. 168-178.

Moniruzzaman, M.S. Rahman, M.R. Karim, and Q.M. Alam. 2009. "Agro-economic analysis of maize production in Bangladesh: a farm level study."Bangladesh J. Agril. Res. 34(1): 15-24.

Rahman, M.S. 2011. "Productivity and sustainability of maize in Bangladesh: Prospects and potentials."Ph.D. dissertation.Department of Agricultural Economics, Bangladesh Agricultural University, Mymensingh.

Roy, M., J. Harris, S.Afreen, E. Deak, L.Gade, S.A.Balajee, B. Park, T. Chiller, and S.Luby. 2013. "Aflatoxin contamination in food commodities in Bangladesh." Food Additives \& Contaminants: Part B. 6(1):17-23.

Uddin, H. 2008. "An economic study of maize production under different farm size groups in selected area of Bangladesh."M.S.thesis submitted to the Department of Agricultural Economics, Bangladesh Agricultural University, Mymensingh. 
